\title{
LHCGR Gene
}

National Cancer Institute

\section{Source}

National Cancer Institute. LHCGR Gene. NCI Thesaurus. Code C158717.

This gene plays a role in luteinizing hormone and choriogonadotropin-mediated signaling. 